\title{
Echocardiographic evaluation of dogs subjected to different protocols of anesthetic induction
}

\section{Helena Mondardo Cardoso ${ }^{1 *}$ Ronise Tocheto $^{1}$ Vanessa Sasso Padilha ${ }^{1}$ Gizelli Silva $^{1}$ Felipe Comassetto ${ }^{1}$ James Newton Bizetto Meira de Andrade ${ }^{2}$ (-) Nilson Oleskovicz ${ }^{1}$}

${ }^{1}$ Universidade do Estado de Santa Catarina (UDESC), 88035-001, Florianópolis, SC, Brasil. E-mail: helenamondardo@yahoo.com.br. *Corresponding author.

${ }^{2}$ Universidade Federal dos Vales do Jequitinhonha e Mucuri, Teófilo Otoni, MG, Brasil.

ABSTRACT: The objective of this study was to investigate the echocardiographic changes during anesthesia induction in dogs sedated with acepromazine $(0.05 \mathrm{mg} / \mathrm{kg})$ and butorphanol $(0.3 \mathrm{mg} / \mathrm{kg})(\mathrm{AB})$. Twenty-four male dogs, with a mean weight of $12.40 \mathrm{~kg} \pm 3.1 \mathrm{~kg}$, were randomly assigned to 4 groups $(n=6)$. Fifteen minutes after administering pre-anesthetic medication, anesthesia with diazepam (0.5mg/kg) and etomidate (1mg/kg) (group DE); diazepam (0.5mg/kg) and ketamine (3mg/kg) (group CD); propofol (4mg/kg) (group P); or ketamine $(1 \mathrm{mg} / \mathrm{kg}$ ) and propofol (3mg/kg) (group CP) was administered to the 6 dogs in each group. Systolic blood pressure (SBP) was measured and echocardiography was performed immediately prior to the application of the sedation protocol (baseline), 15 minutes after sedation (M1), and immediately after anesthesia induction (M2). No significant differences were observed in SBP and in hemodynamic variables such as cardiac index, shortening fraction, and ejection fraction, between groups at all time points (MO, M1, and M2) evaluated. The SBP was significantly reduced after anesthetic induction in the dogs of the DE and CP groups. It can be concluded that the protocols DE and CP reduce similarly to $S P B$ in dogs medicated with CD and P to SBP remain stable after anesthetic induction. All anesthetic induction protocols maintained a stable $I C$ in premedicated dogs. None of the protocols evaluated promoted significant echocardiographic changes. Furthermore, the ketamine and diazepam combination had a negative impact on myocardial relaxation.

Key words: echocardiography, dogs, sedation, induction.

Avaliação ecocardiográfica de cães submetidos a diferentes protocolos de indução anestésica

RESUMO: O aumento crescente da expectativa de vida dos cães, faz com que muitos animais cardiopatas necessitem de um procedimento anestésico-cirúrgico. Os objetivos do estudo foram investigar as alterações ecocardiográficas de protocolos de indução anestésica, em cães sedados com acepromazina (0,05mg/kg) e butorfanol (0,3mg/kg) (AB). Foram utilizados 24 cães, machos, SRD, com peso médio de $12,40 \pm 3,1 \mathrm{~kg}$, os quais foram alocados aleatoriamente em quatro grupos (n=6). Após 15 minutos da medicação pré-anestésica, foi realizada indução anestésica com diazepam $(0,5 \mathrm{mg} / \mathrm{kg}) /$ etomidato $(1 \mathrm{mg} / \mathrm{kg})(\mathrm{DE})$, ou diazepam $(0,5 \mathrm{mg} / \mathrm{kg}) / \mathrm{cetamina}(3 \mathrm{mg} / \mathrm{kg})(\mathrm{CD})$, oupropofol (4mg/kg) (P) ou cetamina (1mg/kg)/propofol (3mg/kg) (CP). Aferiu-se a PAS e ecocardiografia imediatamente antes da aplicação do protocolo de sedação (basal), 15 minutos após a sedação (M1) e imediatamente após a indução anestésica (M2). Não foram observadas diferenças significativas na PAS e nas variáveis hemodinâmicas como índice cardiaco, fração de encurtamento, fração de ejeção, entre os grupos, em todos os momentos avaliados. A PAS reduziu significativamente, após indução anestésica, nos cães do grupo DE e CP. A FC reduziu, após indução, em relação aos valores pós sedação, somente no grupo CD, mantendo-se estável nos demais grupos estudados. Conclui-se que os protocolos DE e CP reduzem de maneira semelhante a PAS, nos cães medicados com CD e P a PAS mantêm-se estável, após indução anestésica. Todos os protocolos de indução anestésica mantém estáveis o IC em cães prémedicados. Nenhum dos protocolos avaliados promove alterações ecocardiográficas significativas. Aassociação cetamina/diazepam tem um impacto negativo no relaxamento miocárdico.

Palavras-chave: ecocardiografia, cães, sedação, indução.

\section{INTRODUCTION}

Invasive hemodynamic monitoring is associated with several difficulties, such as risk to the patient and high cost. In this context, an echocardiogram has been shown to be increasingly useful for the non-invasive assessment of hemodynamic variables (COBUCCI, 2009). This type of examination enables a structural and functional evaluation, taking into account important information about the patient's state of well-being (MANNION, 2006).
In veterinary literature, cardiovascular and respiratory changes are the major causes of anesthetic deaths in small animals; although,gastrointestinal, neurological, renal and hepatic changes have also been reported (REDONDO et al., 2007). According to BILLE (2014), in order to promote reduction in mortality rates due to anesthesia, it is essential to understand the potential depressant effects of anesthetic drugs in the cardiovascular system, so that anesthetic procedures are conducted in the best possible way. 
The aim of this study was to investigate the hemodynamic effects of ketamine and propofol; ketamine and diazepam; propofol and diazepam; and etomidate and diazepam in dogs premedicated with acepromazine and butorphanol.

The systolic blood pressure (SBP) was assessed using a portable vascular Doppler (Doppler 841-A, Parks Medical Electronics, Inc., Aloha, Oregon, USA). The cuff used to measure SBP accounted for approximately $40 \%$ of the circumference of the right thoracic limb, which is standardized for measurements. Five measurements were performed using the mean of these values to obtain a result, as recommended by BROWN et al. (2007).

Echocardiographic examinations were performed using an echocardiography device (HD15 Ultrasound System Philips ${ }^{\circledR}$ Healthcare). With the animal in the right lateral position, the transducer was placed in the right parasternal echocardiographic window, located between the $3^{\text {rd }}$ and $6^{\text {th }}$ intercostal spaces (EIC) and between the sternum and the costochondral joint of the transverse axis, and the echocardiographic measurements were performed. From the long axis, it was possible to obtain the views of the four-chambers and the left ventricle outflow tract. On the short axis, the apical, papillary, chordal, mitral, and aortic sections were observed. From these measurements, the shortening fraction (FS) was obtained. Anatomical relationships between the cardiac structures, morphofunctional valvular aspects, and the myocardial contractility were evaluated; the pressure gradient of the aortic valve was calculated from the left caudal (apical) window. Cardiac output (DC) and ejection fraction (EF) were calculated by the modified Simpson method, as described by SCHILLER et al. (1989). The exclusion criteria of the animals in the study took into account the presence of pre-existing heart diseases and conditions that could prevent the use of the sedation protocol and anesthetic induction.

The sedation protocol comprised the drugs acepromazine $(0.05 \mathrm{mg} / \mathrm{kg})$ and butorphanol $(0.3 \mathrm{mg} / \mathrm{kg})$, which were administered intramuscularly, and 15 minutes after this, the SBP, ECG, and ECO were evaluated (M1). Then, venous access to the right cephalic vein was obtained for anesthesia induction with the following drug combinations: DE group, diazepam $0.5 \mathrm{mg} / \mathrm{kg}$ and etomidate $1 \mathrm{mg} / \mathrm{kg}$; $\mathrm{CD}$ group, diazepam $0.5 \mathrm{mg} / \mathrm{kg}$ and ketamine $3 \mathrm{mg} / \mathrm{kg}$; P group: $\mathrm{NaCl}$ solution $(0.9 \%)(2 \mathrm{~mL})$ associated with propofol at a dose of $4 \mathrm{mg} / \mathrm{kg}$; CP group, ketamine $1 \mathrm{mg} / \mathrm{kg}$ and propofol $3 \mathrm{mg} / \mathrm{kg}$.

Statistical analysis of the parametric data were performed using the one-way ANOVA test with Multiple Repeats, followed by the SNK (Student-
Newman-Keuls) test. For non-parametric data, the Kruskal-Wallis test was conducted, followed by the SNK test and the Wilcoxon Signed Rank Test. Statistically significant data were considered to have a $p$-value of $(\mathrm{p} \leq 0.05)$.

\section{RESULTS AND DISCUSSION}

The mean weight of animals that underwent anesthesia induction with diazepam and etomidate; ketamine and diazepam; propofol; and ketamine and propofol was $10.50 \mathrm{~kg} \pm 3.12 \mathrm{~kg}, 12.81 \mathrm{~kg} \pm 2.51 \mathrm{~kg}$, $12.12 \mathrm{~kg} \pm 3.61 \mathrm{~kg}$, and $14.18 \mathrm{~kg} \pm 2.53 \mathrm{~kg}$, respectively. There was no significant difference between the groups.

Regarding echocardiographic parameters relating to cardiac and aortic dimensions, there was no significant difference between groups and between different time points (M0, M1, and M2) for all parameters (Table 1). No statistical differences were observed for the parameters indicative of systolic function at baseline (M0) between the different groups studied (Table 2 ).

After SBP reduction (M1), SBP reduction was observed in the dogs of the $\mathrm{DE}, \mathrm{CD}$, and $\mathrm{P}$ groups, in which heart rate values remained normal. In contrast, the SBP values remained constant in the group of dogs that received ketamine and propofol; however, there was a reduction in heart rate (Table 2). According to PAPICH (2009), when more than one drug is given at the same time to an individual, or during a time-frame when a previously administered drug is still having its effect in the body, it is possible that drug interactions may occur, which may be beneficial or harmful. In this context, it is important to take into account the possible effects of the pre-anesthetic medication (acepromazine and butorphanol) used in the present study, in association with the different anesthetic induction protocols.

According to CEREJO et al. (2013), acepromazine is routinely used as a pre-anesthetic agent, because in addition to reassuring the animal, it also decreases the dose of anesthetic necessary to anaesthetize animals. Furthermore, it also reduces myocardial sensitization to catecholamines, thus reducing the risk of ventricular arrhythmias (MONTEIRO et al., 2007). However, in spite of these beneficial effects, acepromazine causes vasodilatation mediated by an $\alpha$-adrenergic receptor blockade, which may contribute to the establishment of hypotension during and after the induction of anesthesia (HALL et al., 2001). In contrast, for butorphanol, the main undesirable effect associated with its use is bradycardia, which is caused by the 
Table 1 - Mean values and standard deviation of the aorta diameter (AO) (cm), left atrial diameter (AE) (cm), left atrium ratio and AE / AO aorta; diameter of the right ventricle in diastole (DIVDd) $(\mathrm{cm})$, thickness of the interventricular septum in diastole $(\mathrm{ESIVd})(\mathrm{cm})$, internal diameter of the left ventricle at diastole (DIVEd) $(\mathrm{cm})$, left ventricular free wall thickness at the end of diastole (EPLVEd) $(\mathrm{cm})$, internal left ventricular diameter at systole (DIVEs) $(\mathrm{cm})$, measured by echocardiography in healthy dogs at baseline (M0), after sedation with acepromazine and butorphanol (M1), and during induction (M2) with either diazepam and etomidate (DE group), ketamine and diazepam (CD group), propofol (P) or ketamine and propofol (CP group).

\begin{tabular}{|c|c|c|c|c|c|c|c|c|c|c|c|c|}
\hline & & & ---------------------DE------------ & \multicolumn{3}{|c|}{ 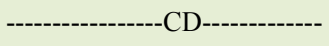 } & \multicolumn{3}{|c|}{------------------P-------------- } & \multicolumn{3}{|c|}{ 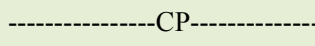 } \\
\hline $\mathrm{AO}(\mathrm{cm})$ & $\begin{array}{c}1.65 \pm \\
0.23\end{array}$ & $\begin{array}{c}1.60 \pm \\
0.16\end{array}$ & $\begin{array}{c}1.60 \pm \\
0.10\end{array}$ & $\begin{array}{c}1.68 \pm \\
0.10\end{array}$ & $\begin{array}{c}1.68 \pm \\
0.10\end{array}$ & $\begin{array}{c}0.66 \pm \\
0.16\end{array}$ & $\begin{array}{c}1.80 \pm \\
0.32\end{array}$ & $\begin{array}{c}1.71 \pm \\
0.29\end{array}$ & $\begin{array}{c}1.70 \pm \\
0.16\end{array}$ & $\begin{array}{c}1.78 \pm \\
0.13\end{array}$ & $\begin{array}{c}1.77 \pm \\
0.10\end{array}$ & $\begin{array}{c}1.73 \pm \\
0.13\end{array}$ \\
\hline $\mathrm{LA}(\mathrm{cm})$ & $\begin{array}{c}1.93 \pm \\
0.28\end{array}$ & $\begin{array}{c}1.86 \pm \\
0.32\end{array}$ & $\begin{array}{c}1.73 \pm \\
0.16\end{array}$ & $\begin{array}{c}1.88 \pm \\
0.23\end{array}$ & $\begin{array}{c}1.86 \pm \\
0.22\end{array}$ & $\begin{array}{c}1.82 \pm \\
0.14\end{array}$ & $\begin{array}{c}1.76 \pm \\
0.85\end{array}$ & $\begin{array}{c}1.88 \pm \\
0.29\end{array}$ & $\begin{array}{c}1.86 \pm \\
0.24\end{array}$ & $\begin{array}{c}1.93 \pm \\
0.18\end{array}$ & $\begin{array}{c}2.05 \pm \\
0.16\end{array}$ & $\begin{array}{c}1.73 \pm \\
0.13\end{array}$ \\
\hline $\mathrm{LA} / \mathrm{AO}$ & $\begin{array}{c}1.18 \pm \\
0.07\end{array}$ & $\begin{array}{c}1.15 \pm \\
0.08\end{array}$ & $\begin{array}{c}1.07 \pm \\
0.04\end{array}$ & $\begin{array}{c}1.11 \pm \\
0.07\end{array}$ & $\begin{array}{c}1.12 \pm \\
0.07\end{array}$ & $\begin{array}{c}1.10 \pm \\
0.06\end{array}$ & $\begin{array}{c}1.13 \pm \\
0.05\end{array}$ & $\begin{array}{c}1.11 \pm \\
0.09\end{array}$ & $\begin{array}{c}1.09 \pm \\
0.07\end{array}$ & $\begin{array}{c}1.07 \pm \\
0.06\end{array}$ & $\begin{array}{c}1.16 \pm \\
0.11\end{array}$ & $\begin{array}{c}1.10 \pm \\
0.08\end{array}$ \\
\hline $\mathrm{RVd}(\mathrm{cm})$ & $\begin{array}{c}0.60 \pm \\
0.11\end{array}$ & $\begin{array}{c}0.49 \pm \\
0.17\end{array}$ & $\begin{array}{c}0.52 \pm \\
0.15\end{array}$ & $\begin{array}{c}0.58 \pm \\
0.13\end{array}$ & $\begin{array}{c}0.67 \pm \\
0.09\end{array}$ & $\begin{array}{c}0.66 \pm \\
0.15\end{array}$ & $\begin{array}{c}0.58 \pm \\
0.12\end{array}$ & $\begin{array}{c}0.61 \pm \\
0.20\end{array}$ & $\begin{array}{c}0.53 \pm \\
0.16\end{array}$ & $\begin{array}{c}0.61 \pm \\
0.16\end{array}$ & $\begin{array}{c}0.62 \pm \\
0.11\end{array}$ & $\begin{array}{c}0.61 \pm \\
0.09\end{array}$ \\
\hline $\mathrm{VSd}(\mathrm{cm})$ & $\begin{array}{c}0.69 \pm \\
0.16\end{array}$ & $\begin{array}{c}0.63 \pm \\
0.13\end{array}$ & $\begin{array}{c}0.67 \pm \\
0.24\end{array}$ & $\begin{array}{c}0.75 \pm \\
0.15\end{array}$ & $\begin{array}{c}0.80 \pm \\
0.11\end{array}$ & $\begin{array}{c}0.75 \pm \\
0.16\end{array}$ & $\begin{array}{c}0.74 \pm \\
0.12\end{array}$ & $\begin{array}{c}0.71 \pm \\
0.14\end{array}$ & $\begin{array}{c}0.65 \pm \\
0.22\end{array}$ & $\begin{array}{c}0.75 \pm \\
0.13\end{array}$ & $\begin{array}{c}0.75 \pm \\
0.10\end{array}$ & $\begin{array}{c}0.77 \pm \\
0.20\end{array}$ \\
\hline $\operatorname{LVd}(\mathrm{cm})$ & $\begin{array}{c}2.81 \pm \\
0.33\end{array}$ & $\begin{array}{c}2.69 \pm \\
0.39\end{array}$ & $\begin{array}{c}2.72 \pm \\
0.31\end{array}$ & $\begin{array}{c}3.34 \pm \\
0, .45\end{array}$ & $\begin{array}{c}3.06 \pm \\
0.18\end{array}$ & $\begin{array}{c}2.79 \pm \\
0.45\end{array}$ & $\begin{array}{c}3.08 \pm \\
0.65\end{array}$ & $\begin{array}{c}3.03 \pm \\
0.59\end{array}$ & $\begin{array}{c}2.70 \pm \\
0.50\end{array}$ & $\begin{array}{c}3.51 \pm \\
0.50\end{array}$ & $\begin{array}{c}3.12 \pm \\
0.35\end{array}$ & $\begin{array}{c}2.99 \pm \\
0.46\end{array}$ \\
\hline LVWd(cm) & $\begin{array}{c}0.81 \pm \\
0.18\end{array}$ & $\begin{array}{c}0.93 \pm \\
0.33\end{array}$ & $\begin{array}{c}0.82 \pm \\
0.15\end{array}$ & $\begin{array}{c}0.79 \pm \\
0.14\end{array}$ & $\begin{array}{c}0.83 \pm \\
0.08\end{array}$ & $\begin{array}{c}0.81 \pm \\
0.07\end{array}$ & $\begin{array}{c}0.86 \pm \\
0.12\end{array}$ & $\begin{array}{c}0.91 \pm \\
0.10\end{array}$ & $\begin{array}{c}0.86 \pm \\
0.12\end{array}$ & $\begin{array}{c}0.89 \pm \\
0.20\end{array}$ & $\begin{array}{c}0.89 \pm \\
0.20\end{array}$ & $\begin{array}{c}0.88 \pm \\
0.10\end{array}$ \\
\hline $\mathrm{LVs}(\mathrm{cm})$ & $\begin{array}{c}1.73 \pm \\
0.26\end{array}$ & $\begin{array}{c}1.63 \pm \\
0.29\end{array}$ & $\begin{array}{c}1.67 \pm \\
0.29\end{array}$ & $\begin{array}{c}1.90 \pm \\
0.32\end{array}$ & $\begin{array}{c}1.73 \pm \\
0.15\end{array}$ & $\begin{array}{c}1.75 \pm \\
0.34\end{array}$ & $\begin{array}{c}1.94 \pm \\
0.50\end{array}$ & $\begin{array}{c}1.93 \pm \\
0.34\end{array}$ & $\begin{array}{c}1.84 \pm \\
0.25\end{array}$ & $\begin{array}{c}2.11 \pm \\
0.15\end{array}$ & $\begin{array}{c}1.95 \pm \\
0.36\end{array}$ & $\begin{array}{c}1.86 \pm \\
0.31\end{array}$ \\
\hline
\end{tabular}

$\mathrm{d}=$ diastole, $\mathrm{s}=$ systole, $\mathrm{AO}=$ aorta, $\mathrm{LA}=$ left atrium, $\mathrm{RV}=$ right ventricle, $\mathrm{VS}=$ ventricular septum, $\mathrm{LV}=$ left ventricle, $\mathrm{LVW}=$ left ventricular wall.

vagal stimulus promoted by this class of drugs (SEO et al., 2014). It also contributes to the decrease in $\mathrm{CD}$, as the variables $\mathrm{FC}$ and $\mathrm{DC}$ behave in a directly proportional way.

For PAS, no significant difference was observed between groups at the different time points (M0, M1, and M2) (Table 2). In the dogs of the DE and CP groups, post-induction SBP reduction was observed in the post-sedation values (M1) (Table 2). These findings differ from those reported by SAMS et al. (2008), who observed a reduction of SBP in dogs anesthetized with propofol, but in those who received etomidate, PAS remained stable. BENDEL et al. (2007) reported that in human patients, the occurrence of hypotension was greater after administration of propofol than when etomidate was administered, which is different from what was observed in the present study. The requirements of phenylephrine in trans-anesthetics also have to be considered. In contrast, KENNEDY and SMITH (2014) did not observe a significant difference in MAP values, measured 5 minutes post induction, in dogs anesthetized with propofol or propofol and ketamine. Furthermore, CANIES et al.
(2014) were unable to observe a reduction of HR, SBP and diastolic blood pressure in dogs submitted to anesthetic induction with propofol; however, the dogs in this study were not premedicated. One factor that may explain the divergence of findings in relation to SBP in the present study, is that SBP was measured immediately after anesthetic induction, and it was not monitored in a sequence that could have possibly led to different results than those observed. This is because in studies conducted on dogs, blood pressure measurement was generally performed after intubation of the patient, which was then evaluated at several subsequent moments. The data were then used for analysis and comparisons were made between the mean of these findings.

In all groups evaluated, no significant changes were observed in FS values (Table 2), which is different from the results of WODEY et al. (1999), who detected a reduction in FS values after anesthetic induction with propofol in children. In contrast, BILLOTA (2001) observed that FS values were maintained after the induction and maintenance of propofol anesthesia in humans, which is in agreement with the findings of the present study. In 
Table 2 - Mean values and standard deviation of the shortening fraction (FS) (\%), ejection fraction (EF) (\%), final diastolic volume (VDF) $(\mathrm{mL})$, final systolic volume $\left(\mathrm{L} / \mathrm{min} / \mathrm{m}^{2}\right)$, heart rate $(\mathrm{HR})$, systolic blood pressure (SBP), maximum systolic peak velocity aortic flow (VmxAo) $(\mathrm{cm} / \mathrm{s})$, maximum systolic peak velocity pulmonary artery flow (Vmx PA) (cm/s), measured by echocardiography in healthy dogs at baseline (M0), during sedation with acepromazine and butorphanol (M1), and during induction (M2) with either diazepam and etomidate (DE group), ketamine and diazepam (CD group), propofol (P) or ketamine and propofol (CP group)

\begin{tabular}{|c|c|c|c|c|c|c|c|c|c|c|c|c|}
\hline & \multicolumn{3}{|c|}{----------------DE-------------- } & \multicolumn{3}{|c|}{ 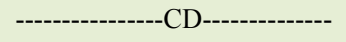 } & \multicolumn{3}{|c|}{--------------------'P----------------- } & \multicolumn{3}{|c|}{ 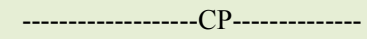 } \\
\hline & M0 & M1 & M2 & M0 & M1 & M2 & M0 & M1 & M2 & M0 & M1 & M2 \\
\hline FS & $\begin{array}{c}38.8 \pm \\
5.0\end{array}$ & $\begin{array}{c}37.6 \pm \\
3.7\end{array}$ & $\begin{array}{c}38.6 \pm \\
5.0\end{array}$ & $\begin{array}{c}45.5 \pm \\
3.9\end{array}$ & $\begin{array}{c}43.0 \pm \\
5.2\end{array}$ & $\begin{array}{c}37.4 \pm \\
5.0\end{array}$ & $\begin{array}{c}37.4 \pm \\
5.5\end{array}$ & $\begin{array}{c}36.3 \pm \\
3.35\end{array}$ & $\begin{array}{c}31.5 \pm \\
4.8\end{array}$ & $\begin{array}{c}39.1 \pm \\
7.3\end{array}$ & $37.4 \pm 7.2$ & $37.3 \pm 7.1$ \\
\hline $\mathrm{EF}^{*}$ & $\begin{array}{c}74.8 \pm \\
4.45\end{array}$ & $\begin{array}{c}73.7 \pm \\
8.5\end{array}$ & $\begin{array}{c}68.1 \pm \\
16.7\end{array}$ & $\begin{array}{c}65.8 \pm \\
5.3\end{array}$ & $\begin{array}{c}72.5 \pm \\
6.6\end{array}$ & $\begin{array}{c}59.7 \pm \\
11.8\end{array}$ & $\begin{array}{c}63.0 \pm \\
10.8\end{array}$ & $\begin{array}{c}67.4 \pm \\
6.3\end{array}$ & $\begin{array}{c}61.0 \pm \\
8.0\end{array}$ & $\begin{array}{c}63.1 \pm \\
15.1\end{array}$ & $71.3 \pm 7.0$ & $72.8 \pm 4.5$ \\
\hline $\mathrm{EDV}^{*}$ & $\begin{array}{c}18.5 \pm \\
7.0\end{array}$ & $\begin{array}{c}17.0 \pm \\
7.7\end{array}$ & $\begin{array}{c}16.8 \pm \\
6.8\end{array}$ & 23.54 .5 & $\begin{array}{c}24.5 \pm \\
8.7\end{array}$ & $\begin{array}{c}23.6 \pm \\
3.5\end{array}$ & $\begin{array}{c}23.0 \pm \\
11.2\end{array}$ & $\begin{array}{c}21.7 \pm \\
12.4\end{array}$ & $\begin{array}{c}21.2 \pm \\
11.7\end{array}$ & $\begin{array}{c}24.7 \pm \\
2.3\end{array}$ & $25.9 \pm 4.6$ & $23.3 \pm 6.2$ \\
\hline $\mathrm{ESV}^{*}$ & $\begin{array}{c}4.5 \pm \\
1.5\end{array}$ & $\begin{array}{c}4.8 \pm \\
3.5\end{array}$ & $\begin{array}{c}4.8 \pm \\
2.8\end{array}$ & $\begin{array}{c}8.1 \pm \\
2.2\end{array}$ & $\begin{array}{c}6.9 \pm \\
3.2\end{array}$ & $\begin{array}{c}9.5 \pm \\
3.0\end{array}$ & $\begin{array}{c}9.2 \pm \\
6.2\end{array}$ & $7.1 \pm 5.2 \mathrm{~A}$ & $8.6 \pm 5.4 \mathrm{~B}$ & $9.0 \pm 3.4$ & $7.3 \pm 2.3$ & $6.4 \pm 2.3$ \\
\hline $\mathrm{SV}^{*}$ & $\begin{array}{c}14.0 \pm \\
5.7\end{array}$ & $\begin{array}{c}12.1 \pm \\
4.5\end{array}$ & $\begin{array}{c}11.9 \pm \\
5.2\end{array}$ & $\begin{array}{c}17.6 \pm \\
6.3\end{array}$ & $\begin{array}{c}17.5 \pm \\
6.3\end{array}$ & $\begin{array}{c}14.0 \pm \\
3.5\end{array}$ & $\begin{array}{c}13.8 \pm \\
5.3\end{array}$ & $\begin{array}{c}14.7 \pm 7 \\
4\end{array}$ & $12.6 \pm 6.7$ & $\begin{array}{c}15.6 \pm \\
4.3\end{array}$ & $\begin{array}{c}18.4 \pm \\
3.5\end{array}$ & $16.8 \pm 4.1$ \\
\hline $\mathrm{CO}^{*}$ & $\begin{array}{c}1.32 \pm \\
0.36\end{array}$ & $\begin{array}{l}0.93 \pm \\
0.21 \mathrm{~A}\end{array}$ & $\begin{array}{l}0.78 \pm \\
0.27 \mathrm{~A}\end{array}$ & $\begin{array}{c}1.54 \pm 0 \\
.31\end{array}$ & $\begin{array}{c}1.26 \pm \\
0.36\end{array}$ & $\begin{array}{c}1.17 \pm \\
0.22\end{array}$ & $\begin{array}{c}1.35 \pm \\
0.45\end{array}$ & $\begin{array}{c}0.98 \pm 0 \\
54 \mathrm{~A}\end{array}$ & $\begin{array}{l}1.02 \pm \\
0.46 \mathrm{~A}\end{array}$ & $\begin{array}{c}1.61 \pm \\
0.36\end{array}$ & $\begin{array}{l}1.32 \pm \\
0.43 \mathrm{~A}\end{array}$ & $\begin{array}{l}1.36 \pm \\
0.44 \mathrm{~A}\end{array}$ \\
\hline CI & $\begin{array}{l}2.7 \pm \\
0.26\end{array}$ & $\begin{array}{c}1.8 \pm \\
0.26 \mathrm{~A}\end{array}$ & $\begin{array}{c}1.6 \pm \\
0.58 \mathrm{~A}\end{array}$ & $\begin{array}{l}2.8 \pm \\
0.33\end{array}$ & $\begin{array}{l}2.2 \pm \\
0.73\end{array}$ & $\begin{array}{l}2.1 \pm \\
0.55\end{array}$ & $\begin{array}{l}2.4 \pm \\
0.40\end{array}$ & $1.7 \pm 0.6 \mathrm{~A}$ & $\begin{array}{c}1.8 \pm \\
0.49 \mathrm{~A}\end{array}$ & $2.6 \pm 0.55$ & $2.1 \pm 0.5 \mathrm{~A}$ & $\begin{array}{c}2.3 \pm \\
0.57 \mathrm{~A}\end{array}$ \\
\hline HR & $\begin{array}{c}105 \pm \\
21\end{array}$ & $92 \pm 24$ & $\begin{array}{c}73 \pm \\
24 \mathrm{AB}\end{array}$ & $\begin{array}{c}102 \pm \\
28\end{array}$ & $83 \pm 23$ & $\begin{array}{r}87 \pm \\
23.1\end{array}$ & $97 \pm 22$ & $70 \pm 8.3 \mathrm{~A}$ & $88 \pm 21$ & $110 \pm 20$ & $81 \pm 17 \mathrm{~A}$ & $95 \pm 27$ \\
\hline SAP & $\begin{array}{c}179 \pm \\
25\end{array}$ & $\begin{array}{c}148 \pm \\
5 \mathrm{~A}\end{array}$ & $\begin{array}{c}120 \pm \\
13 \mathrm{AB}\end{array}$ & $\begin{array}{c}196 \pm \\
25\end{array}$ & $\begin{array}{c}164 \pm 2 \\
6 A\end{array}$ & $\begin{array}{l}155 \pm \\
30 A\end{array}$ & $187 \pm 34$ & $\begin{array}{c}140 \pm \\
17 \mathrm{~A}\end{array}$ & $118 \pm 19 \mathrm{~A}$ & $173 \pm 16$ & $152 \pm 22$ & $\begin{array}{c}123 \pm \\
20 \mathrm{AB}\end{array}$ \\
\hline $\begin{array}{l}\text { Vma } \\
\text { x Ao }\end{array}$ & $\begin{array}{c}140.5 \pm \\
17.7\end{array}$ & $\begin{array}{c}142.5 \pm \\
2.2\end{array}$ & $\begin{array}{c}125.7 \pm \\
19.8 \mathrm{AB}\end{array}$ & $\begin{array}{c}166.3 \pm \\
24.7\end{array}$ & $\begin{array}{c}167.2 \pm \\
24.8\end{array}$ & $\begin{array}{c}135.1 \pm \\
30.9 \mathrm{AB}\end{array}$ & $\begin{array}{c}145.2 \pm \\
16.0\end{array}$ & $\begin{array}{c}133.2 \pm \\
7.9\end{array}$ & $\begin{array}{c}104.6 \pm \\
21.5 \mathrm{AB}\end{array}$ & $\begin{array}{c}154.3 \pm \\
30.7\end{array}$ & $\begin{array}{c}156.2 \pm \\
39.4\end{array}$ & $\begin{array}{c}132.2 . \pm \\
20.6 \mathrm{AB}\end{array}$ \\
\hline $\begin{array}{l}\text { Vma } \\
\mathrm{X} \\
\text { PA }\end{array}$ & $\begin{array}{c}124.0 \pm \\
18.9\end{array}$ & $\begin{array}{c}122.8 \pm \\
18.2\end{array}$ & $\begin{array}{c}102.6 \pm \\
13.6\end{array}$ & $\begin{array}{c}135.5 \pm \\
16.7\end{array}$ & $\begin{array}{c}139.8 \pm \\
19.4\end{array}$ & $\begin{array}{c}112.7 \pm \\
8.6\end{array}$ & $\begin{array}{c}110.7 \pm \\
16.8\end{array}$ & $\begin{array}{c}113.3 \pm \\
97.4\end{array}$ & $\begin{array}{c}97.4 \pm \\
19.0\end{array}$ & $\begin{array}{c}117.0 \pm \\
13.5\end{array}$ & $\begin{array}{c}110.5 \pm \\
24.2\end{array}$ & $\begin{array}{c}105.2 \pm \\
12\end{array}$ \\
\hline
\end{tabular}

$\mathrm{FS}=$ fractional shortening, $\mathrm{EF}=$ ejection fraction, $\mathrm{EDV}=$ end diastolic volume, $\mathrm{ESV}=$ end systolic volume, $\mathrm{SV}=$ systolic volume, $\mathrm{CO}=$ cardiac output, $\mathrm{CI}=$ cardiac index, $\mathrm{HR}=$ heart rate, $\mathrm{SAP}=$ systolic arterial pressure, $\mathrm{VmxAo}=$ maximum velocity of aorta, $\mathrm{VmaxPA}=$ maximum velocity of pulmonary.

Upper case letters indicate significant difference when compared to basal (M0), One Way RM ANOVA, followed by Student-NewmanKeuls (SNK), where A, is different from M0; and B, is different from M1 ( $<<0.05)$.

${ }^{*}$ Calculated by the modified Simpson method.

addition, LOPES et al. (2009) were unable to detect a significant reduction in FS values in dogs who were not premedicated, but were anesthetized with propofol. In the present study, in all groups tested, it was confirmed that etomidate $(0.4-3.2 \mathrm{mg} / \mathrm{kg}$ ) and propofol reduced LV FS in the hearts of the dogs submitted to extracorporeal circulation. However, no difference was observed between etomidate and propofol nor was there a difference between ketamine and propofol. However, it was determined that when etomidate was compared to equipotent doses of ketamine, it reduced LV FS twice as much and decreased myocardial contractility.

None of the protocols evaluated reduced cardiac index (HF) values after the induction of anesthesia, since after the induction of the anesthetic there was no reduction in HF, when compared to the post-sedation values (Table 2). These findings suggest that the sedation protocol may have caused a significant depressor effect, culminating in a similar pattern of CD reduction in all groups. The fact that only the dogs of the ketamine and diazepam group maintained a stable CI supports this hypothesis, because occasionally, in this group, the same sedation protocol was used as for the other groups, and it did not cause a significant reduction in HF values after sedation. Consequently, this difference did not appear after anesthetic induction. RODRIGUEZ et al. (2012) cite that etomidate promotes insignificant changes in CD and HF, as observed in the present study. Furthermore, BRUSSEL et al. (1989) did not observe a significant reduction in DC values in dogs 
anesthetized with etomidate and DC was similar to that in dogs who were anesthetized with propofol. These results are similar to those observed in the present study. FAYYAZ (2009) did not observe a significant difference in HF values in dogs anesthetized with ketamine and diazepam and with propofol and diazepam, which is similar to the results observed in this study.

There was no significant difference between moments nor between groups for the assessment of anesthetic depth (Table 3 ). The peak velocity of the $\mathrm{E}$ and $\mathrm{A}$ waves of the mitral valve $(\mathrm{E} / \mathrm{A})$ parameters did not present with significant changes between moments and between groups studied (Table 3 ).

In the evaluation of diastolic function, a significant increase in the isovolumetric relaxation time after anesthetic induction, was observed in dogs receiving ketamine and diazepam (Table 3), which according to LESTER et al. (2008) may indicate abnormal myocardial relaxation. According to LIN (2013), the increased coronary blood flow induced by ketamine may be insufficient to meet the demand for oxygen by the myocardium, and may consequently alter the relaxation of the cardiac muscle. This could explain the alterations in IVRT reported in the present study, as these were only observed in the animals that received ketamine in larger doses. However, in spite of evidence for diastolic dysfunction, dogs administered ketamine and diazepam did not present a reduction in final diastolic volume, as assessed by the modified Simpson method. This suggests that in healthy animals, under the conditions of the present study, the combination of ketamine and diazepam cannot affect the diastolic filling of the heart, which provides maintenance of cardiac index values. This is despite the fact that this combination of drugs can affect myocardial relaxation.

\section{CONCLUSION}

According to the conditions under which this study was performed, it can be concluded that all evaluated protocols of anesthetic induction reduced blood pressure similarly. No significant cardiovascular and hemodynamic changes were observed in dogs that were premedicated with acepromazine and butorphanol and underwent different anesthesia induction protocols. However, the ketamine and diazepam combination promoted a significant reduction in myocardial relaxation.

Table 3 - Mean values and standard deviation of the relation between the peak velocity of the E and A waves of the mitral valve (E / A), isovolumetric relaxation time (IVR), the relationship between the lateral velocity peak E 'and A (E / A'lat), the relationship between the peak velocity of the medial E' and medial A' waves (E '/ A'med), measured by echocardiography at baseline (M0) and during sedation (M1). This was measured in the superficial plane (0), ideal plane (1), and deep plane (3), in healthy dogs sedated with acepromazine and butorphanol, and anesthetic depth scores performed immediately after induction (M0) and after the echocardiogram (M1), and during induction (M2) with either diazepam and etomidate (DE group), ketamine and diazepam (CD group), propofol (P) or ketamine and propofol (CP group).

\begin{tabular}{|c|c|c|c|c|c|c|c|c|c|c|c|c|}
\hline & \multicolumn{3}{|c|}{-------------------DE------------' } & \multicolumn{3}{|c|}{ 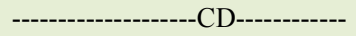 } & \multicolumn{3}{|c|}{-----------------------P--------------- } & \multicolumn{3}{|c|}{ 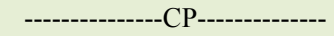 } \\
\hline & M0 & M1 & M2 & M0 & M1 & M2 & M0 & M1 & M2 & M0 & M1 & M2 \\
\hline Wave E & $\begin{array}{c}84.31 \pm \\
18.39\end{array}$ & $\begin{array}{c}81.63 \pm \\
21.73\end{array}$ & $\begin{array}{c}84.32 \pm \\
18.4\end{array}$ & $\begin{array}{c}90.05 \pm \\
11.66\end{array}$ & $\begin{array}{c}107.32 \pm \\
16.43\end{array}$ & $\begin{array}{c}90.05 \pm \\
11.66\end{array}$ & $\begin{array}{c}76.30 \pm \\
22.33\end{array}$ & $\begin{array}{c}79.80 \pm \\
14.33\end{array}$ & $\begin{array}{c}76.30 \pm \\
22.33\end{array}$ & $\begin{array}{c}88.82 \pm \\
20.57\end{array}$ & $\begin{array}{c}93.97 \pm \\
17.14\end{array}$ & $\begin{array}{r}88.82 \pm \\
20.57\end{array}$ \\
\hline Wave A & $\begin{array}{c}53.08 \pm \\
11.44\end{array}$ & $\begin{array}{c}50.40 \pm \\
8.27\end{array}$ & $\begin{array}{c}56.92 \pm \\
14.11\end{array}$ & $\begin{array}{c}65.85 \pm \\
18.06\end{array}$ & $\begin{array}{c}65.85 \pm \\
10.84\end{array}$ & $\begin{array}{c}63.20 \pm \\
10.86\end{array}$ & $\begin{array}{c}56.33 \pm \\
6.05\end{array}$ & $\begin{array}{c}69.17 \pm \\
24.85\end{array}$ & $\begin{array}{c}53.20 \pm \\
13.46\end{array}$ & $\begin{array}{c}64.28 \pm \\
9.51\end{array}$ & $\begin{array}{c}61.52 \pm \\
17.16\end{array}$ & $\begin{array}{r}64.30 \pm \\
15.35\end{array}$ \\
\hline $\mathrm{E} / \mathrm{A}$ & $\begin{array}{c}1.61 \pm \\
0.29\end{array}$ & $\begin{array}{c}1.63 \pm \\
0.45\end{array}$ & $\begin{array}{c}1.49 \pm \\
0.08\end{array}$ & $\begin{array}{c}1.44 \pm \\
0.31\end{array}$ & $\begin{array}{c}1.66 \pm \\
0.28\end{array}$ & $\begin{array}{c}1.43 \pm \\
0.10\end{array}$ & $\begin{array}{c}1.35 \pm \\
0.34\end{array}$ & $\begin{array}{c}1.23 \pm \\
0.33\end{array}$ & $\begin{array}{c}1.44 \pm \\
0.22\end{array}$ & $\begin{array}{c}1.40 \pm \\
0.39\end{array}$ & $\begin{array}{c}157 \pm \\
0.2\end{array}$ & $\begin{array}{c}1.42 \pm \\
0.27\end{array}$ \\
\hline $\operatorname{IVRT}(\mathrm{m})$ & $55 \pm 4$ & $56 \pm 7$ & $63 \pm 1$ & $57 \pm 8$ & $57 \pm 5$ & $69 \pm 5 B$ & $54 \pm 7$ & $60 \pm 4$ & $67 \pm 12$ & $54 \pm 1$ & $59 \pm 1$ & $65 \pm 7$ \\
\hline Score 0 & - & $\begin{array}{c}5 / 6 \\
(83.3 \%)\end{array}$ & - & $\begin{array}{c}5 / 6 \\
(83.3 \%)\end{array}$ & $\begin{array}{c}5 / 6 \\
(83.3 \%)^{*}\end{array}$ & - & $\begin{array}{c}4 / 6 \\
(66.7 \%)\end{array}$ & $\begin{array}{c}6 / 6 \\
(100 \%)\end{array}$ & - & $\begin{array}{c}5 / 6 \\
(83.3 \%)\end{array}$ & $\begin{array}{c}6 / 6 \\
(100 \%)\end{array}$ & - \\
\hline Score 1 & $\begin{array}{c}3 / 6 \\
(50 \%)\end{array}$ & $\begin{array}{c}1 / 6 \\
(16.7 \%)\end{array}$ & - & $\begin{array}{c}1 / 6 \\
(16.7 \%)\end{array}$ & - & - & $\begin{array}{c}2 / 6 \\
(33.3 \%)\end{array}$ & - & - & $\begin{array}{c}1 / 6 \\
(16.7 \%)\end{array}$ & - & - \\
\hline Score 2 & $\begin{array}{c}3 / 6 \\
(50 \%)\end{array}$ & - & - & - & - & - & - & - & - & - & - & - \\
\hline
\end{tabular}

Wave $\mathrm{E}=$ mitral valve $\mathrm{E}$ peak, Wave $\mathrm{A}=$ mitral valve A peak, IVRT= isovolumic relaxation time, Score = refers to the anesthetic plane Upper case letters indicate significant difference when compared to basal (M0), Multiple Way Variance Analysis (One Way RM Anova), followed by Student-Newman-Keuls (SNK), where A, is different from M0; and B, is different from M1 ( $<<0.05)$. ${ }^{*} 1$ animal was excited and awake at the end of the echocardiogram. 


\section{BIOETHICS AND BIOSSECURITY COMMITTEE APPROVAL}

The present study was approved by the Ethics and Animal Welfare Committee (CETEA) of the institution of origin, protocol number 1.45 .13 .

\section{ACKNOWLEDGEMENTS}

To the Support Fund for the Maintenance and Development of Higher Education - FUNDES / State Secretariat of Education of Santa Catarina; and the Graduate Program in Animal Science of the CAV-UDESC, for the development aid.

\section{DECLARATION OF CONFLICTING OF INTERESTS}

The authors declare no conflict of interest. The founding sponsors had no role in the design of the study; in the collection, analyses, or interpretation of data; in the writing of the manuscript, and in the decision to publish the results.

\section{REFERENCES}

BENDEL, S. et al. Propofol causes more hypotension than etomidate in patients with severe aortic stenosis: a double-blind, randomized study comparing propofol and etomidate. Acta. Anaesthesiol. Scand., vol. 51, p. 284-289, 2007.

BILLE, C. et al. An evidence-based medicine approach to small animal anaesthetic mortality in a referral practice: the influence ofinitiating three recommendations on subsequente anaesthetic deaths. Vet. Anaesth. Analg., vol. 41, p. 249-258, 2014.

BILlOTA, F. et al. Cardiovascular effects of intravenous propofol administered at two infusion rates: a transthoracic echocardiographic study. Anaesthesia, v. 56, p. 266-271, 2001.

BOON, J. A. Veterinary Echocardiography. $2^{\text {a }}$ ed. Oxford: Wiley-Blackwell, 480p. 2011

BROWN, S.A. et al. Diagnosis of systemic hipertension in dogs and cats. In: BONAGURA, J.D. Small Animal Pratice. Philadelphia: WB Saunders, 2000, p. 835-838.

BRUSSEL, T. et al. Hemodynamic and Cardiodynamic Effects of Propofol and Etomidate: Negative Inotropic Properties of Propofol. Anesth. Analg.,vol. 69, p. 35-40, 1989.

CANIES, D. et al.. Comparison of isoflurane and propofol for maintenance of anesthesia in dogs with intracranial disease undergoing magnetic resonance imaging, Vet. Anaesth. Analg., vol. 41, p. 468-479, 2014

CEREJO, S.A. et al. Effects of constant rate infusion of anesthetic or analgesic drugs on general anesthesia with isoflurane: A retrospective study in 200 dogs. Semina, v. 34, n. 4, p. 1807$1822,2013$.

COBUCCI, A.O Papel da Ecocardiografia na Monitoração Hemodinâmica do Doente Crítico. Rev bras ecocardiogramagemcardiovasc, v. 22, n. 3, p. 26-34, 2009
FAYYAZ, S. et al. The cardiopulmonar effects of anesthetic induction with isoflurane, ketamine-diazepam or propofoldiazepam in the hypovolemic dog. Vet. Anaesth. Analg.,vol. 36, p. $110-123,2009$.

HALL, L.W. et al. Principles of sedation, analgesia and premedication. In: Veterinary Anaesthesia and Analgesia. 10 ed. London: W. B. Saunders, cap 4, p. 75-112, 2001

KENNEDY, M.J.; SMITH, L. A comparison of cardiopulmonary function, recovery quality, and total dosages required for induction and total intravenous anesthesia with propofol versus a propofolketamine combination in healthy Beagle dogs. Vet. Anaesth. Analg., vol. 41, p. 1-10, 2014

LESTER, S.J. et al. Unlocking the mysteries of diastolic function: deciphering the Rocetta Stone 10 years later. J. Am. Coll. Cardiol, vol. 51, p. 679-689, 2008

LIN, H.C. Anestésicos dissociativos. In: TRANQUILI, W.L. et al. Anestesiologia e Analgesia Veterinária. 4 ed. São Paulo: Roca, cap. 4, p. 335-384, 2013.

LOPES, P.C.F. et al. Efeitos de diferentes FiO2 sobre variáveis ecocardiográfica sem cães submetidos à infusão contínua de propofol. Arq. Bras. Med. Vet. Zootec., v. 61, n. 2, p. 345-352, 2009.

MANNION, P. Diagnostic ultrasound in small animal Practice. Oxford: Blackwell Publishing, 338 p., 2006.

MONTEIRO, E.R. et al. Effects of acepromazine on the cardiovascular actions of dopamine in anesthetized dogs. Vet. Anaesth. Analg., vol. 34, p. 312-321, 2007.

PAPICH, M.G. Interações farmacológicas. In: REVIERE, J.E.;

PAPICH, M.G.J. Vet. Pharmacol. Ther. 9a ed. Ames: WileyBlackwell, p. 167-189, 2009.

REDONDO, J.I. et. al. Normal values and incidence of cardio respiratory complications in dogs during general anaesthesia. A review of 1281 cases. J Vet Med., vol. 54, p. 470-477, 2007.

RODRIGUEZ, J.M.; MUNOZ, P.; ROCIO, N.R.; Comparison of the cardiopulmonary parameters after induction of anaesthesia with alphaxalone or etomidato in dogs. Vet. Anaesth. Analg., vol. 39 , p. 357-365, 2012.

SAMS, L. et al A comparison of the effects of propofol and etomidate on the induction of anesthesia and on cardiopulmonary parameters in dogs. Vet. Anaesth. Analg., vol. 35, p. 488-494, 2008.

SEO, J.I. et al. Cardiopulmonary and anesthetic effects of the combination of butorphanol, midazolam and alfaxalone in Beagle dogs. Vet. Anaesth. Analg., 2014

SCHILLER, N.B. et al. Recommendations for quantitation of the left ventricule by two-dimensional echocardiography: Americam Society of Echocardiography Committee on Standards Subcommittee. J. Am. Soc. Ech., v.2, n. 5, p. 358-367, 1989.

WODEY, E.; CHONOW, L.; BENEUX, X. et al.Haemodynamic effects of propofol vs thiopental in infants: an echocardiographic study. Br. J. Anaesth., v. 82, p. 516-520, 1999. 